ACCEPTED FOR PUBLICTION

AUTHORS SUBMISSION VERSION

Please cite the RPG version of this paper using the following

DOI: 10.1049 /iet-rpg.2014.0042

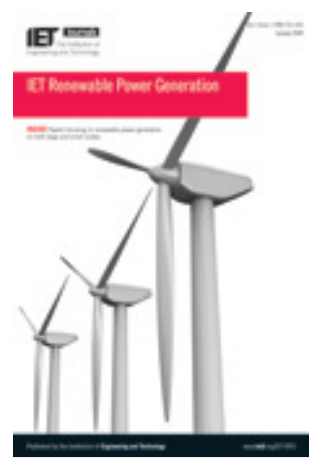

Energy storage against interconnection as a balancing mechanism for a $100 \%$ renewable UK electricity grid

Author(s): Marcus Joseph Alexander; Patrick James; Neil Richardson Source: IET Renewable Power Generation, $11 \mathrm{pp}$.

DOI: 10.1049/iet-rpg.2014.0042, Available online: 10 September 2014 


\title{
Energy storage versus interconnection as a balancing mechanism for a $100 \%$ renewable UK electricity grid
}

Marcus Joseph Alexander*, , Patrick James', Neil Richardson'

\author{
' Faculty of Engineering and the Environment, University of Southampton, \\ Southampton, SO17 1BJ, UK \\ *E-mail:mja105@soton.ac.uk
}

\begin{abstract}
This study considers generation and demand challenges of a $100 \%$ renewable UK electricity grid and how this can be addressed with interconnection or energy storage. Hourly demand and electricity generation profiles for a year have been constructed: Business as Usual (BAU) with a yearly demand of 540TWh and Green Plus (GP) with a demand of 390TWh. In addition, two extra scenarios based on the above have been considered with electrification of heating (ASHP) and transportation (EV). The resultant hourly imbalances have been used to calculate the interconnection and energy storage requirements. The present paper discusses the findings of the BAU scenario. The calculated interconnector capacity required was found to be $60 \mathrm{GW}$ and cost $£ 58$ billion. Energy storage capacity requirements vary depending on the selected technology. Rated capacity was estimated to be $14 \mathrm{GW}$ with storage capacity of $3 \mathrm{TWh}$ for pumped storage, $11 \mathrm{GW}$ and $2.3 \mathrm{TWh}$ for liquid air, and 65CW and 13.6TWh for hydrogen storage, at a cost of $£ 65$, $£ 76$ and $£ 45$ billion respectively. This paper indicates that storing hydrogen in underground caverns would offer the cheapest solution. However, whilst
\end{abstract}


these technological solutions can address generation and demand imbalance in a fully renewable electricity grid, there remain barriers to each technology.

\section{Background}

It is highly likely that an extensive de-carbonisation of the energy supply sector as is highlighted by the targets set by the European Commission Roadmap 2050 [1] will mandatory in the future. The UK Low Carbon Transition Plan [2] includes energy sources such as wave, tidal, geothermal and solar, but mainly onshore and offshore wind as likely technologies to provide carbon free electricity generation. These sources are, by their very nature, variable and in most cases unpredictable which creates challenges for distribution, grid stability and standby plant [3]. At present, the real-time balancing of the supply and demand of electricity on the electricity grid is carried out by flexible fossil fuelled power plants which are capable of increasing or decreasing output rapidly as required by the grid operator. However, in a future renewable only electricity grid network, this balancing will have to be achieved using alternative technologies such as demand side management, interconnectors and energy storage.

For these reasons, various studies have been conducted to investigate the applicability of using $100 \%$ renewable energy in various systems. These studies have been undertaken using a variety of methods from a global [4] and continental [5-7] scale, as well as for countries: Denmark [8], Macedonia [9], Croatia [10], Portugal [11], Ireland [12], New Zealand [13], and Australia [14]; municipalities: Aalborg [15]; cities: Frederikshavn [16]; islands: Island 
of Mljet [17], Island of S. Vicente [18] and Island of Porto Santo [19].The overall conclusion is that the development of such systems with existing technologies is possible and "it is not a matter of technology, but rather a matter of making the right choices today to shape tomorrow" [20]. This is to say that if issues related to public perception of renewable technologies, such as visual aesthetic, and the upfront capital cost are addressed, then current technology is capable of delivering the required energy demands. However, at present, balancing and variability remain an issue unless a country or region has access to suitable energy storage such as large capacity pumped hydro.

A number of studies discuss the importance of integrating renewables with the heating sector, creating a whole energy system. This is the case of Denmark, whereby variable generation from renewable sources is being successfully integrated with the district heating network that provides consumers with heat from combined heat and power (CHP) plants [21-23]. However, the constraints of existing UK heat and electricity networks mean that the integration of these systems is unlikely in the near future and therefore for this study is omitted at this point.

This study considers the generation and demand challenge of a $100 \%$ renewable UK electricity grid and how this can be addressed with interconnection or energy storage. Some of the main drivers and barriers considered are illustrated in Figure 1. 


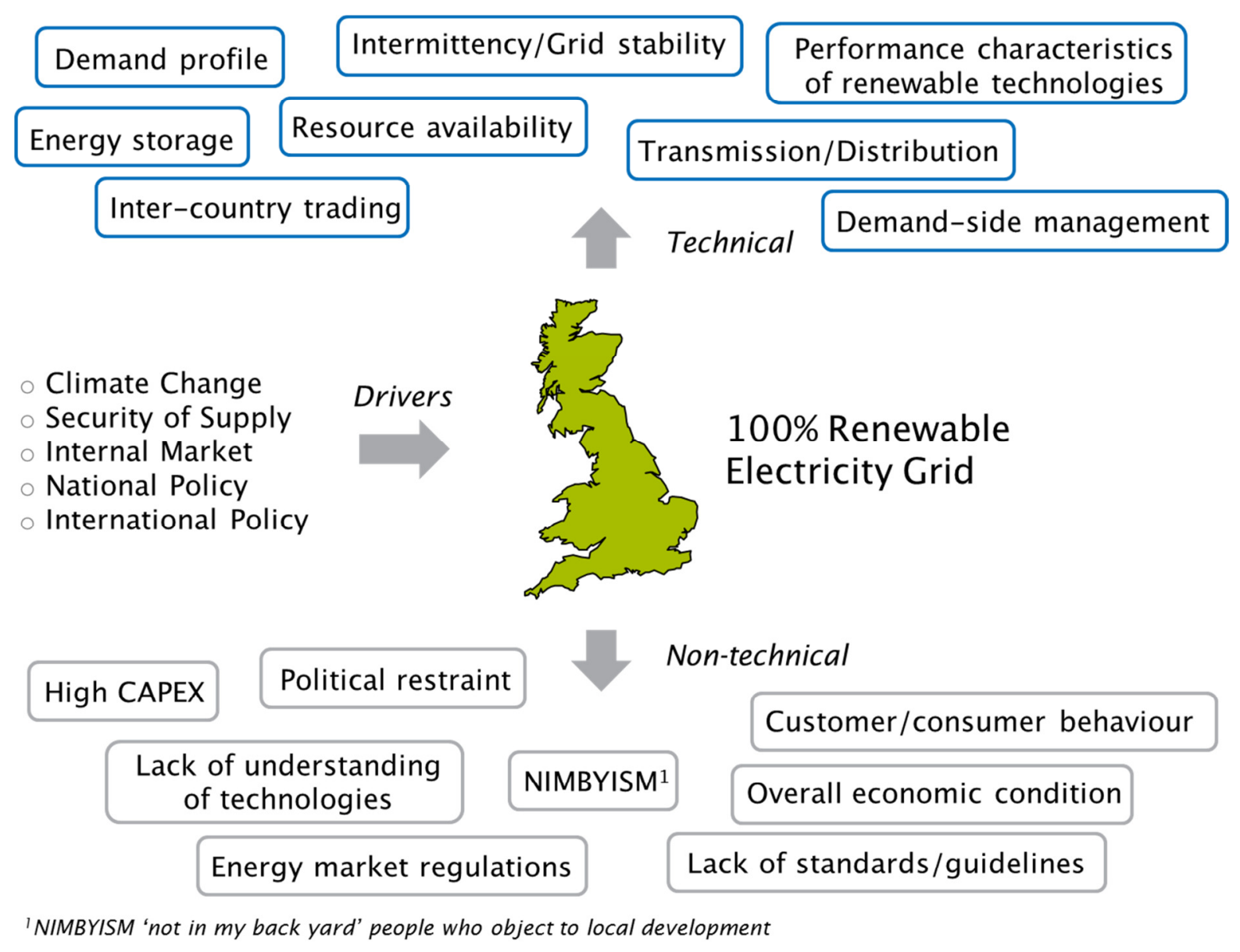

Figure 1: Schematic of barriers and drivers to a 100\% renewable electricity grid

\section{Approach}

This study focuses on creating a viable future UK electricity mix using renewable energy sources and achieving balancing of generation and demand through interconnection or energy storage. The main aim is to ensure security of supply throughout the year. This focus was chosen to investigate the potential technological solutions to ensure electricity demand is met in a hypothetical future scenario where there is no use of fossil fuels, therefore no use of carbon capture and storage (CCS) technologies, and no external imports of fuel, meaning no nuclear generation. In reality, it appears that by 2050 there will be up to $18 \mathrm{GW}$ of new nuclear operating on the UK 
grid, operated as base load generation throughout the year. This effectively acts as an offset to the scenarios considered here. The assumption for this study is that the UK is considered as an isolated grid, except when investigating the use of interconnection with the European electricity network. In this instance, it is assumed that the European network is capable of meeting all of the UK import and export requirements fully if suitably sized. The study only considers a snapshot view of the year 2050 and does not consider the grid development up to the scenario in question. However, where there are planned and proposed network upgrades and renewable capacity developments, these have been included where appropriate in the study. The study also focuses on the high voltage (HV) transmission network owned and operated by National Grid (NG), the transmission system operator (TSO) for the UK. To enable a better understanding of the demand requirements within this network, NG has divided the network using 17 boundaries which confine areas or zones within the grid that are considered as blocks that have their own generation and demand requirements [24]. The system zones are depicted in Figure 8. Each zone has a number of electricity generators within it. However, not all generation in each zone is consumed within the zone; therefore in some cases there is a transmission of excess generation to neighbouring zones where there is a demand. This produces power flows between zones around the network towards the centres of consumption in cities and generally from North to South 


\section{Methodology}

To form the model, hourly or half-hourly data has been collected where possible for electricity demand and generation from renewable energy sources (RES) on the UK electricity network. The year 2011 has been chosen as the baseline as it provides an up to date dataset and was found to be an 'average' year, based on the ratio of the yearly minimum to maximum demand compared with the previous 10 years. In terms of the weather, 2011 was found to be $0.5^{\circ} \mathrm{C}$ above the 1971-2000 average temperature [25].It was also found that the average wind speed of $4.6 \mathrm{~m} / \mathrm{s}$ in 2011 was $0.05 \mathrm{~m} / \mathrm{s}$ higher than the 10 year mean (2002 to 2011 ), however, it was shown to be less windy than average in the first quarter of the year and the reverse was observed in the final quarter of the year [26]. These factors make the 2011 demand profile representative of 'normal' operation of the electricity network. The main sources of data collected for this study and the way in which they are used are described in Table 1.

Table 1: Sources of data collected to model a 100\% renewable UK electricity grid

\begin{tabular}{|l|l|l|}
\hline \multicolumn{1}{|c|}{ Data collected } & \multicolumn{1}{c|}{ Use in modelling } \\
\hline $\begin{array}{l}\text { Half-hourly electricity } \\
\text { demand data for the UK in } \\
2011\end{array}$ & $\begin{array}{l}\text { Data averaged to produce an } \\
\text { hourly demand profile for the UK } \\
\text { which has subsequently been } \\
\text { scaled up for future scenarios }\end{array}$ & [27] \\
\hline $\begin{array}{l}\text { Half-hourly electricity } \\
\text { generated from onshore } \\
\text { wind data for the UK in } 2011\end{array}$ & $\begin{array}{l}\text { Data averaged to produce an } \\
\text { hourly generation profile from } \\
\text { wind which has been scaled and } \\
\text { used for future onshore wind } \\
\text { supply }\end{array}$ & [28] \\
\hline $\begin{array}{l}\text { Hourly wind data at selected } \\
\text { UK weather stations for 2011 } 11\end{array}$ & $\begin{array}{l}\text { Data used in the calculation of } \\
\text { potential output from future } \\
\text { offshore wind farms }\end{array}$ & {$[29]$} \\
\hline $\begin{array}{l}\text { Hourly simulation output } \\
\text { from High Resolution UK } \\
\text { Continental Shelf (UKCS) } \\
\text { Model of Pentland Firth, }\end{array}$ & $\begin{array}{l}\text { Data used to calculate potential } \\
\text { future output from tidal stream } \\
\text { technology }\end{array}$ & {$[30]$} \\
\hline
\end{tabular}




\begin{tabular}{|l|l|l|}
\hline Scotland, for 2001 & & \\
\hline Hourly solar irradiation, air & Data required for input into & [29] \\
temperature, wind speed and & TRNSYS (Transient Systems & \\
dew point data from & Simulation Program) model to & \\
Cambourne (Cornwall), & create an hourly PV output & \\
Heathrow (London), Church & profile for use in future & \\
Fenton (Yorkshire) and & scenarios & \\
Edinburgh (Scotland) & & \\
weather stations for 2011 & & \\
\hline
\end{tabular}

For the purposes of this study it was decided to consider two future demand scenarios that have been introduced by Elders, Ault [31] to illustrate how demand can be met by renewable energy sources and the requirements needed to maintain security of supply. In addition, the effect of electrification of domestic heating and hot water of 34 million households, calculated as the housing stock in the UK in 2050 assuming demolition of old housing stock, refurbishment of existing and new build [32], using air source heat pumps (ASHP) and the uptake of 7 million plug-in electric vehicles (EV) has been added to each scenario. This number has been calculated using an existing projection of $\sim 500,000$ battery electric vehicles (BEV) and 1.5 million plug-in hybrid vehicles (PHEV) by 2030 [33]. It is assumed that there is an accelerated growth for each vehicle class by 2050 to 2 million BEV and 5 million PHEV. The selected demand scenarios used and their respective demands are given in Table 2 . This selection provides four fundamentally different, yet plausible demand scenarios for discussion.

Table 2: Scenario characteristics for use in study (Sources: Elders, Ault [31] and DECC [34])

\begin{tabular}{|l|c|c|}
\hline \multicolumn{1}{|c|}{ Scenario name } & $\begin{array}{c}\text { Average annual } \\
\text { demand growth }\end{array}$ & $\begin{array}{c}2050 \text { electricity } \\
\text { demand (TWh) }\end{array}$ \\
\hline Business as Usual (BAU) & $+1 \%$ & 540 \\
\hline Green Plus (GP) & $+0.25 \%$ & 390 \\
\hline BAU + ASHP \& EV & $+2 \%$ & 677 \\
\hline GP + ASHP \& EV & $+1 \%$ & 527 \\
\hline
\end{tabular}


The hourly 2011 demand profile determined from actual data has been linearly scaled to match the projected future annual electricity demands in each of the scenarios introduced. In the case of the original scenarios with ASHP and EV, it has been assumed that heating demand only occurs during the six winter months (October through to March), whereas hot water demand and vehicle charging demand will occur uniformly throughout the year. It has been proposed that demand-side management of the electricity load will be used in the future in order to control daily peak loads. Blecourt [35] suggests that up to $16 \%$ of the domestic peak can be shifted to the 'valley' hours during the night using smart appliances. A review of past and present demand-side trials has concluded that flexible loads have the potential to reduce peak demand between $1 \%$ and $12 \%$ [36]. It has been assumed for this study that $10 \%$ of the demand of the top six hours in each day can be shifted to the lowest six hours using flexible loads in the domestic and industrial sectors, thereby reducing peak demand requirements.

A report by Gardner [37] has estimated the total UK renewable energy resource capacity as well as the practicable capacity that can be exploited. The capacities discussed in Gardner [37] have been used as the base from which the four scenarios have been calculated. It was found however that, given the demand projections used in this study, more installed capacity would be required than has been calculated in the scenarios used by Gardner [37]. Differences were also found in load factors and generation yield from 
investigations of actual weather data. Therefore, it has been assumed that for the purposes of this study the capacity of offshore wind will be scaled to meet the respective demand scenarios whilst the balance of the installed capacity (onshore wind, PV, tidal, bioenergy, hydro and geothermal) remains unchanged across all four scenarios and that the calculated load factors and yield from existing weather data are used. The renewable installed capacity and yearly generation mix given by Gardner [37] and the calculated capacity and generation mix by scenario of this study are summarised in Table 3.

These capacities have been calculated as the minimum installed mix required to meet the yearly electricity demand for each scenario and do not, at this stage, consider the effects of variability of generation.

Table 3: Assumed practicable resource capacity (GW) and generation (TWh) and calculated mix for each scenario: Business as Usual (BAU), Green Plus $(G P), B A U$ with electrification of heating and transportation (BAU+ASHP\&EV) and GP with electrification of heating and transportation (GP+ASHP\&EV) (Source: adapted from Gardner [37])

\begin{tabular}{|c|c|c|c|c|c|}
\hline Technology & $\begin{array}{c}\text { Gardner } \\
\text { [37] } \\
\text { (GW/TWh) }\end{array}$ & $\begin{array}{c}\text { BAU } \\
\text { (GW/TWh) }\end{array}$ & $\begin{array}{c}\text { GP } \\
\text { (GW/TWh) }\end{array}$ & $\begin{array}{c}\text { BAU + } \\
\text { ASHP \& EV } \\
\text { (GW/TWh) }\end{array}$ & $\begin{array}{c}\text { GP+ ASHP } \\
\& \text { EV } \\
\text { (GW/TWh) }\end{array}$ \\
\hline $\begin{array}{l}\text { Onshore } \\
\text { wind }\end{array}$ & $30 / 80$ & $30 / 65$ & $30 / 65$ & $30 / 65$ & $30 / 65$ \\
\hline $\begin{array}{l}\text { Offshore } \\
\text { wind }\end{array}$ & $82 / 310$ & $86 / 288$ & $41 / 138$ & $127 / 425$ & $82 / 275$ \\
\hline Solar PV & $18 / 15$ & $34 / 37$ & $34 / 37$ & $34 / 37$ & $34 / 37$ \\
\hline Tidal & $2 / 7$ & $2 / 7$ & $2 / 7$ & $2 / 7$ & $2 / 7$ \\
\hline Bioenergy & $12 / 95$ & $14 / 95$ & $14 / 95$ & $14 / 95$ & $14 / 95$ \\
\hline Hydro & $4 / 13$ & $2 / 13$ & $2 / 13$ & $2 / 13$ & $2 / 13$ \\
\hline Geothermal & $5 / 35$ & $5 / 35$ & $5 / 35$ & $5 / 35$ & $5 / 35$ \\
\hline $\begin{array}{l}\text { Estimated } \\
\text { scenario } \\
\text { CAPEX }(£ B n)\end{array}$ & $£ 249$ & $£ 280$ & $£ 200$ & $£ 353$ & $£ 273$ \\
\hline
\end{tabular}

The estimated capital expenditure (CAPEX) costs per scenario have been calculated using projected technology capital costs for $2030[38,39]$ and are described in Table 3. Note that these costs represent the full cost of 
installing the required future renewable capacity if it were to be commissioned and installed in one year.

The 2011 wind generation profile obtained from ELEXON, the balancing and settlement code company, is used as the onshore wind generation profile for the future scenarios from which the average load factor for the year has been used to calculate the generation output. The extra required capacity is assumed to be installed in existing wind farms across the UK. The offshore wind generation profile has been calculated using calculated load factors and wind speeds for the Round 3 offshore wind farm locations set out in the UK Offshore Wind Report [40], and assuming a range of future wind turbine sizes up to a maximum of $10 \mathrm{MW}$ obtained from proposed developments in the Round 3 sites [41]. As discussed, these have been scaled for each scenario in order to meet the calculated demand. For the purpose of this study, it has been assumed that solar photovoltaic (PV) capacity will be distributed rather than at concentrated installations or solar farms due to land cover issues and planning constraints [42]. Additionally, recent government policy is looking at biasing installation of PV systems to rooftops in the future [43]. For these reasons, the PV capacity has been calculated assuming installation on a nominal third of all UK households, calculated as being 26 million in 2011 for the whole of the UK [44, 45]. The installed system per household would be $3 \mathrm{~kW}$, taking up a total of $24 \mathrm{~m}^{2}$ per roof, assuming the use of present day monocrystalline technology. Existing installation data of PV systems up to $4 \mathrm{~kW}$ shows that in the year $2013,1.5 \%$ of the building stock installed PV systems across the UK [46], suggesting 
that the proposed target is achievable if current uptake is maintained. The UK housing data was divided up into the National Grid transmission zones, and from this each zone was assigned to the nearest of four weather stations as detailed in Table 4:

Table 4: Distribution of housing by zone and weather station

\begin{tabular}{|l|c|}
\multicolumn{1}{|c|}{ Weather Station } & Encompassing Zones \\
\hline Edinburgh (Scotland) & $\mathrm{Z} 1-\mathrm{Z6}$ \\
\hline Church Fenton (Yorkshire) & $\mathrm{Z} 7-\mathrm{Z} 11$ \\
\hline Heathrow (London) & $\mathrm{Z} 12-\mathrm{Z} 16$ \\
\hline Cambourne (Cornwall) & $\mathrm{Z} 17$ \\
\hline
\end{tabular}

PV generation from each zone was calculated using TRNSYS [47] to give a yearly generation profile based on 2011 weather data and given the constraints that $50 \%$ of the housing stock with PV systems installed have South facing projections and of the remainder each have 25\% East and West facing projections at a suitable slope of $30^{\circ}$ from horizon. The tidal resource in the UK is estimated to be one of the best in Europe, with around 50\% of the European resource in UK waters [48]. However, due to environmental constraints and the difficulty in extracting the resource, it has been assumed that generation is restricted to the Pentland Firth in Scotland as this is one of the best resources available and poses least constraints in terms of exploiting the resource. The generation profile has been calculated based on modelling output from the National Oceanography Centre's High Resolution UKCS model [30] for the Pentland Firth and existing tidal current conversion characteristics [49]. These technologies, onshore wind, offshore wind, distributed PV and tidal, make up the variable generation of the future scenarios considered in this study. 
It has been assumed for this study that the available capacity from hydro, bioenergy and geothermal are available as dispatchable generation and are operated only when the output from wind generation is less than the demand profile. The yearly generation output for these technologies was carried over from the Gardner [37] report, however the installed capacity has been adjusted to reflect the new operation regime. Bioenergy capacity is assumed to be centralised plant that has been converted from coal burning plant [50]. The increased capacity of $14 \mathrm{GW}$ is still within the estimated maximum exploitable UK bioenergy capacity of 22 GW [37]. The geothermal potential in the UK has been investigated by Sinclair Knight Merz (SKM [51]. The findings of this report conclude that there is enough capacity to supply the $5 \mathrm{GW}$ of resource required for this study and also provides an estimate of the output by region. Gardner [37] suggests that a hydro capacity of 4 GW is required in the future, however it was found that the additional future capacity in England and Wales is estimated at up to only 248 MW [52] and for Scotland up to $657 \mathrm{MW}$ [53]. Given the operating schedule of hydro in this study, a lower capacity of $2 \mathrm{GW}$ was chosen, including existing installed capacity, which is within future additional resource estimates.

Figure 2 illustrates the model inputs and outputs considered for this study. It was assumed that there would be a degree of demand-side management available to help reduce the effects of peak demand throughout the day. For this study it was assumed that $10 \%$ of the demand load of the six peak hours could be 'time-shifted' to the valley hours, the six hours when demand is at its lowest. 
The main points discussed next are generation variability, balancing mechanisms and the power flows across the UK network for the BAU scenario.

\section{Balanced UK electricity}

supply and demand

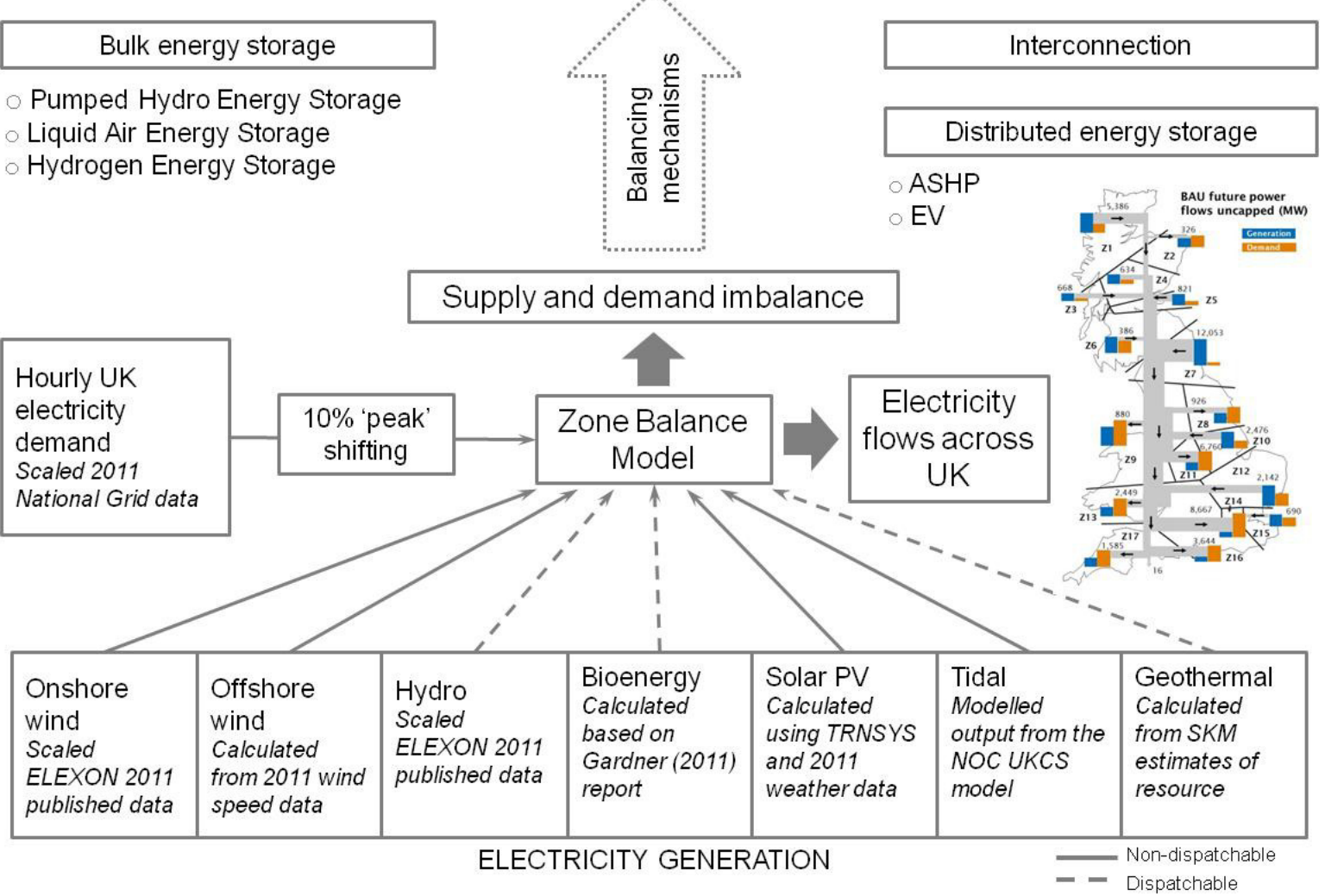

Figure 2: Schematic of the balanced UK electricity supply and demand model inputs and outputs

\section{Results}

As discussed, this study focuses on the fully renewable UK electricity grid.

Having such a scenario means that it is inevitable that the generation of electricity will be variable due to the nature of the sources. One of the main issues occurs when generation from renewables does not meet the demand and balancing mechanisms need to be put in place for these events [54]. 
Given the data, future demand and renewable yield estimate approaches, UK grid demand profiles were generated for the future scenarios and representative generation profiles from the various RES. Figure 3 depicts the demand profile for the BAU scenario that has a maximum demand of $89 \mathrm{GW}$ during the winter and minimum of $40 \mathrm{GW}$ during the summer. It also illustrates the generation profile from wind, onshore and offshore combined, the variable generation from solar PV and tidal, and the total dispatchable generation from hydro, bioenergy and geothermal. It can be seen that the main generation comes from wind with a peak output of $105 \mathrm{GW}$. However, there are large portions of the year during which wind output is less than the minimum demand. The overall contribution from PV and tidal is relatively small with a maximum output of $28 \mathrm{GW}$ during the summer. The total dispatchable generation that is available when the variable generation is below demand is $21 \mathrm{GW}$.

The key rules followed to obtain these profiles are:

Variable generation $=$ Gen $_{\text {wind }}+$ Gen $_{\text {solarPV }}$

Dispatchable generation $=$ Gen $_{\text {hydro }}+$ Gen $_{\text {bioenergy }}+$ Gen $_{\text {geothermal }}$

Dispatchable generation run $\rightarrow$ Variable $_{\text {gen }}<$ Demand 

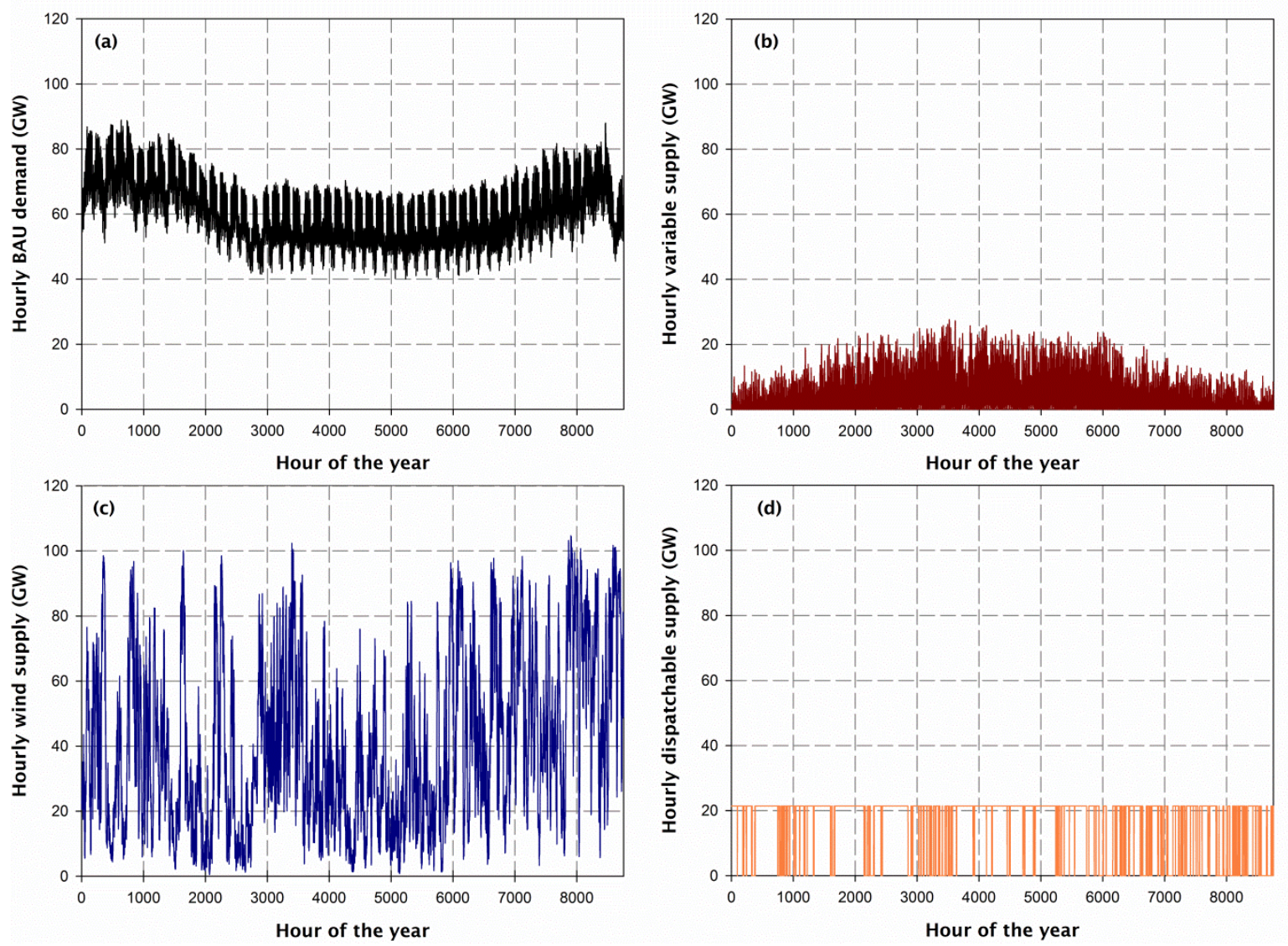

Figure 3: a) calculated BAU demand profile; b) calculated combined PV and tidal output profile; c) calculated wind output profile; d) calculated combined dispatchable (bioenergy, hydro and geothermal) output profile

It should be noted that the maximum output predicted from RES in this scenario is almost double the required demand in that period. This illustrates the magnitude of the generation and demand imbalance challenge throughout the year.

This process has been undertaken for all four scenarios. These datasets provide the specification of the generation and demand balance that must be achieved through options such as interconnection or energy storage. 


\subsection{Option 1: Interconnection}

A potential solution to balancing the variability of generation from RES is by using neighbouring electricity grids as a source that can provide generation when RES generation is below demand, and a source of demand when there

is excess generation from RES. In the UK, this is already achieved at a limited level through sub-sea HVDC cables known as interconnectors to France, Ireland and Belgium. Due to the physical process of transmitting electricity via HVDC interconnectors, this typically carries a loss penalty of $2 \%$ of the transmitted electricity [55]. The current installed capacity is 4GW and it provides a balancing mechanism between the UK grid and the grid of the connected countries [56]. The use of interconnectors to integrate large quantities of RES has been investigated widely and has been highlighted as a major contributor to enabling high penetrations of variable generation on the electricity network $[57,58]$. A major study of future wind penetration scenarios and the enabling characteristics of interconnection found that investing in interconnection for scenarios with high levels of wind power reduced network constraints and maximised the use of RES [59]. Work by Czisch and Giebel [60] also point to the possibility of creating a 'supergrid' of $\mathrm{HV}$ interconnection to maximise integration of large renewable resources over large footprints in order to ensure security of supply.

This study considers interconnection as a solution to the generation-demand imbalance from a fully renewable electricity generation network as one possible solution, assuming the interconnector is able to balance the active and reactive power in the system, like a slack bus. Figure 4 depicts the 
import and export requirements of an interconnector for the whole year in the BAU scenario needed to maintain a balanced grid from which it is possible to calculate the interconnector requirements. It was found that the export requirements exceed the import requirements in all scenarios.

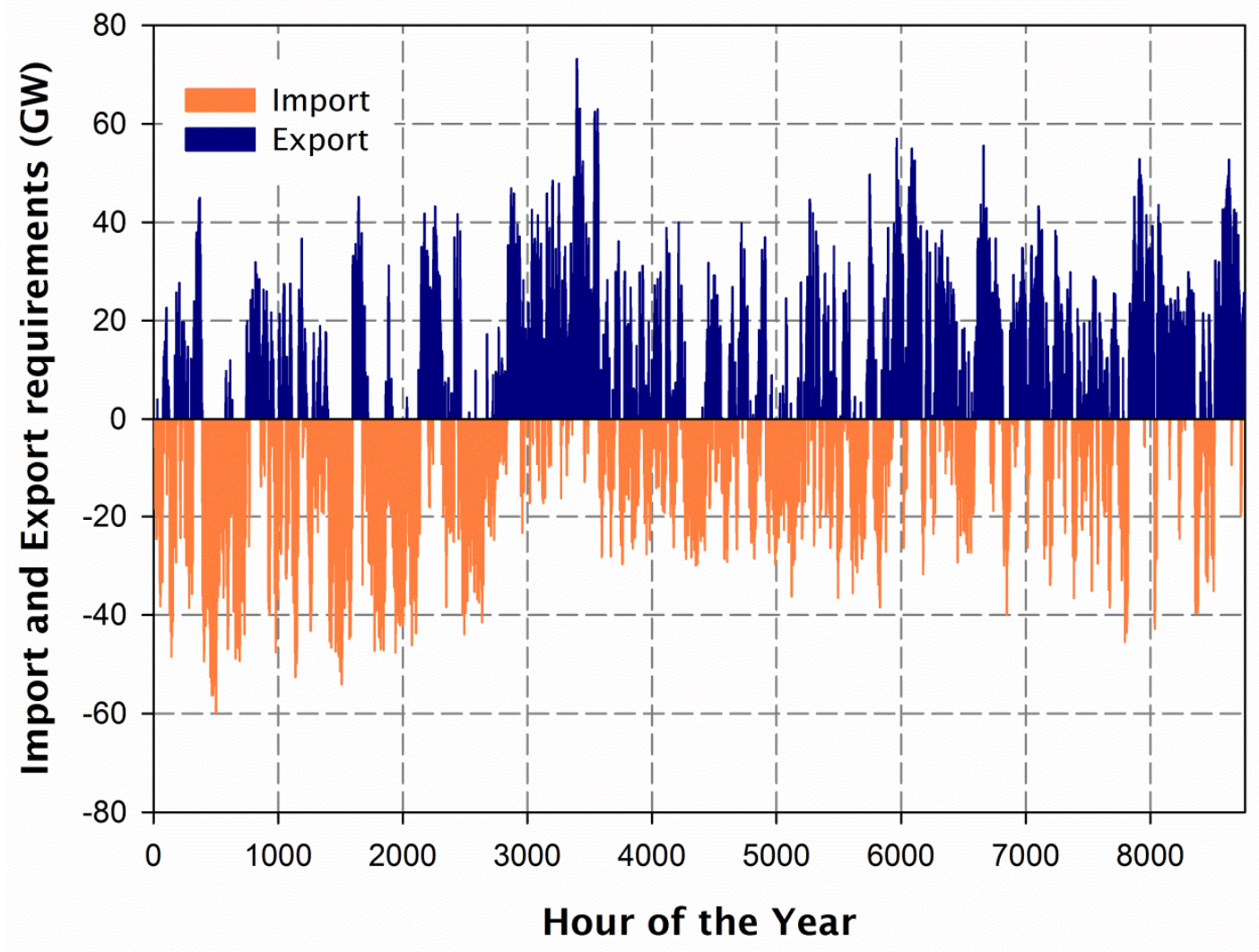

Figure 4: Calculated BAU scenario hourly import and export requirements to maintain grid balance

The required interconnector capacities for all four scenarios are summarised in Table 5. Due to the losses incurred in the transmission of electricity via the interconnector, the installed offshore wind capacity is increased to account for this.

Table 5: Calculated import and export requirements for each scenario

\begin{tabular}{|l|c|c|}
\hline \multicolumn{1}{|c|}{ Scenario } & Import capacity (GW) & Export capacity (GW) \\
\hline BAU & 60 & 73 \\
\hline GP & 40 & 45 \\
\hline
\end{tabular}




\begin{tabular}{|l|c|c|}
\hline BAU + ASHP\&EV & 83 & 104 \\
\hline$G P+$ ASHP\&EV & 62 & 76 \\
\hline
\end{tabular}

In order to maintain grid stability and ensure demand is met, the crucial capacity that would need to be delivered is the import capacity. For the occasions when there is excess generation over the capacity limit of the interconnector, it is assumed that the electricity can be sold to industry to produce hydrogen, for example, or the generation can be shed through reducing the output from wind farms. As has been discussed, the present interconnector capacity is $4 \mathrm{GW}$ so proposing scenarios with up to $83 \mathrm{GW}$ of interconnector capacity is difficult to envisage at present, even if the European grid's capability is not considered as a limitation. The economics of such a scenario have been investigated. To estimate the capital costs of the interconnectors, it has been assumed that existing and proposed future UK-Europe interconnector routes are used. These include connecting the UK with France, Belgium, Norway and Iceland [61]. Cost estimates provided by the Research Methodologies and Technologies for the Effective Development of Pan-European Key Grid Infrastructures to Support the Achievement of a Reliable, Competitive and Sustainable Electricity Supply (REALISEGRID) project [62] have been used to give the interconnector costs based on distance between countries, capacity, technology used and landing terminals at either end. The calculated costs are also compared to the UK gross domestic product (GDP) in 2012 of $£ 1.5$ trillion [63]. The summary of interconnector costs can be seen in Table 6 . 
Table 6: Calculated UK interconnector cost for each scenario (\% of UK GDP in 2012 also shown)

\begin{tabular}{|l|c|c|}
\multicolumn{1}{|c|}{ Scenario } & $\begin{array}{c}\text { Import capacity cost } \\
\text { in } £ \text { Bn (\%GDP) }\end{array}$ & $\begin{array}{c}\text { Export capacity cost } \\
\text { in } £ \text { Bn (\%GDP) }\end{array}$ \\
\hline BAU & $58(3.6 \%)$ & $71(4.4 \%)$ \\
\hline GP & $39(2.4 \%)$ & $44(2.7 \%)$ \\
\hline BAU + ASHP\&EV & $80(4.9 \%)$ & $100(6.2 \%)$ \\
\hline GP + ASHP\&EV & $60(3.7 \%)$ & $73(4.5 \%)$ \\
\hline
\end{tabular}

Further analysis suggests that there is no economic case for adding interconnector capacity beyond the import requirement. Figure $5 \mathrm{~b}$ ) shows the level of excess generation there would be if the interconnector is capped and the cost of increasing the capacity of the interconnector. It was found that the lowest cost to increase the interconnector in the BAU scenario was $£ 4,500 / \mathrm{MWh}$. Conversely, Figure 5 a) shows that for the capped interconnector it is possible to obtain revenue from the sale of excess electricity generation to industry; however, these revenues are an order of magnitude lower than the interconnector cost. Taking a wholesale electricity price of $£ 70 / \mathrm{MWh}$ [64], a revenue of nearly $£ 5$ million could be realised from the excess renewable generation. Table 7 summarises the findings from this analysis.

Table 7: Summary of excess generation, cost to increase interconnector and sales revenue for each scenario

\begin{tabular}{|l|c|c|c|}
\multicolumn{1}{|c|}{ Scenario } & $\begin{array}{c}\text { Excess } \\
\text { generation } \\
(\mathbf{M W h})\end{array}$ & $\begin{array}{c}\text { Cost to increase } \\
\text { interconnector } \\
(£ / \mathbf{M W h})\end{array}$ & $\begin{array}{c}\text { Revenue from } \\
\text { electricity sales } \\
(£ \mathbf{M})\end{array}$ \\
\hline BAU & 70,000 & 4,500 & 4.9 \\
\hline GP & 16,000 & 7,600 & 1.1 \\
\hline BAU + ASHP\&EV & 180,000 & 2,800 & 12.5 \\
\hline GP + ASHP\&EV & 85,000 & 4,000 & 5.9 \\
\hline
\end{tabular}



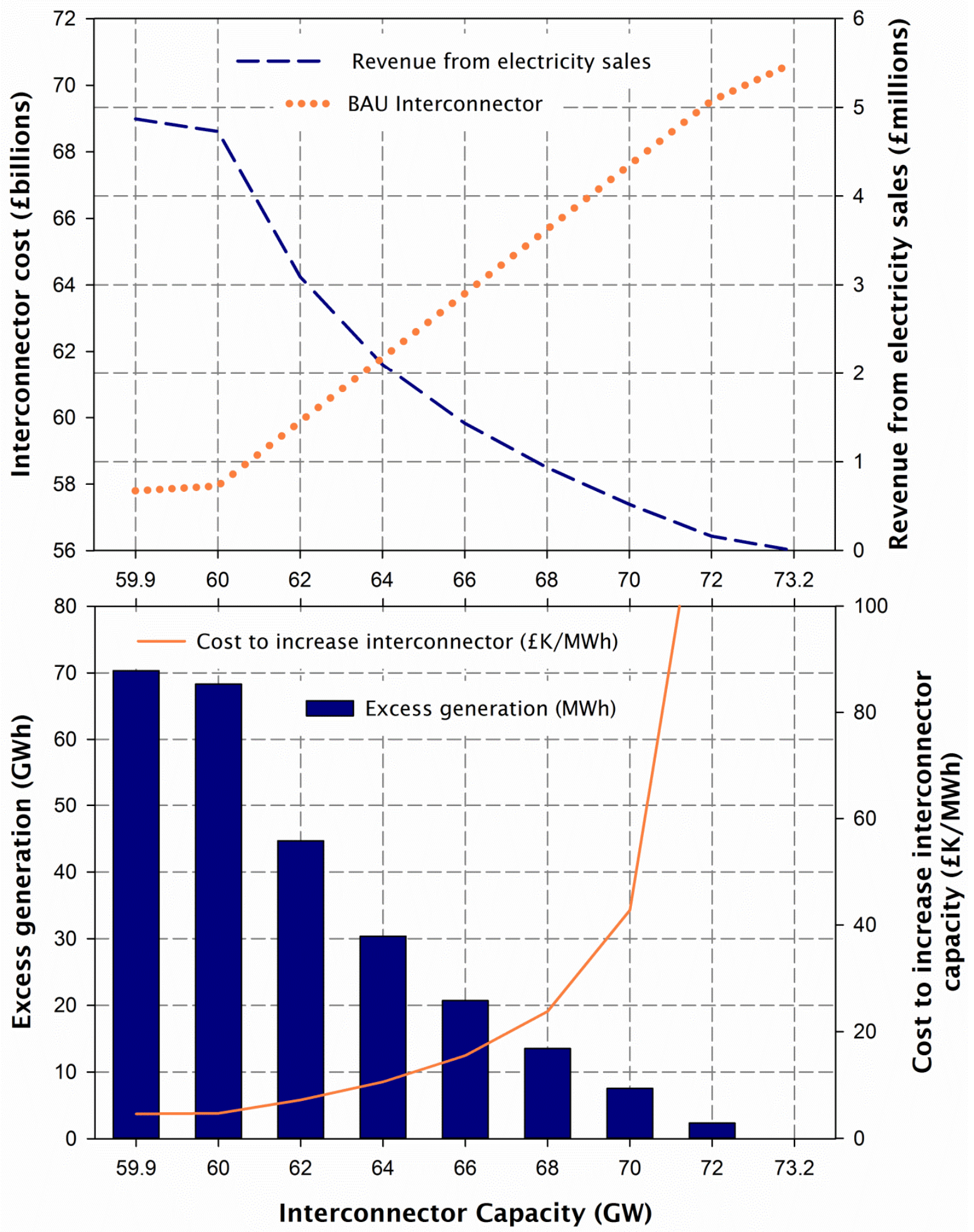

Figure 5: a) BAU interconnector capital vs. revenue from electricity sales; $b$ ) excess electricity from capped interconnector vs. cost to increase interconnector capacity 


\subsection{Option 2: Energy Storage}

The second potential solution investigated to enable grid balancing of the highly variable renewable generation is energy storage. The benefits of energy storage in electricity networks have been investigated by numerous authors, especially when considering high penetrations of variable generation from renewables [65]. Grant-Wilson, McGregor [66] investigated the optimum size of energy storage in the UK network and the potential benefits or drawbacks when compared in conjunction with interconnection or carbon capture and storage (CSS). A further study highlights the ability of energy storage to provide multiple services to the electricity network and not only for the integration of renewable generation [67]. The applications for energy storage in the UK are investigated in Taylor et al. (2012), the conclusion of which is that the UK network will need a combination of large scale and small, decentralised, energy storage including thermal storage. However, energy storage will only become beneficial when there are increased levels of renewable generation.

There are a number of studies that review the various energy storage technologies and applicability of these for the integration of renewable energy sources into electricity grids as well as other ancillary services that they can provide [68], [69], [70], [71]. One important study considers compressed air energy storage (CAES) to enable the integration of wind generation onto the electricity grid in the United States [72]. In the study, the benefits of the location of the CAES system on the network relative to the generation site is calculated and compared to the cost of installing additional 
transmission capacity to remote off-network areas. This approach is not considered in the specific case of this study as it assumed that the majority of renewable generation will be from offshore wind farms. Therefore it is assumed that the cost of installing connections to the grid network will be a necessity and there are substantial technological issues with co-locating storage with generation off-shore.

It is proposed for this study to only consider technologies capable of storing large quantities of electricity over long periods, as likely requirements are in the order of 43TWh. It is further assumed that, at this stage, only three large scale technologies that connect directly to the high voltage (HV) network are discussed for comparison, therefore discounting technologies such as flywheels, batteries and supercapacitors, even if aggregated in such a way as to provide the required storage requirements.

From the variability investigation it is possible to estimate the energy storage requirements for each scenario. The storage requirements can be calculated by running a cumulative total of the hourly import and export requirements over the year. The energy storage size is determined through an iterative process, whereby the 'store' is assumed to begin full with a capacity ' $X$ ' at the start of the year and is iteratively resolved to a storage ' $Y$ ' at the end of the year. When there is an import requirement (e.g. generation is less than demand) the 'store' starts to empty until there is an excess of generation (e.g. export requirement) when the 'store' starts to refill. Figure 6 highlights that the lowest point, or the empty point of the 'store', is reached at 30TWh at hour 2,800 for the BAU scenario, after which there is sufficient net 
generation over the remainder of the year to end the year full. This profile was observed as the wind speeds in 2011 happened to be lower than average in the first quarter of the year, when demand was high, and higher than average in the last quarter of the year.

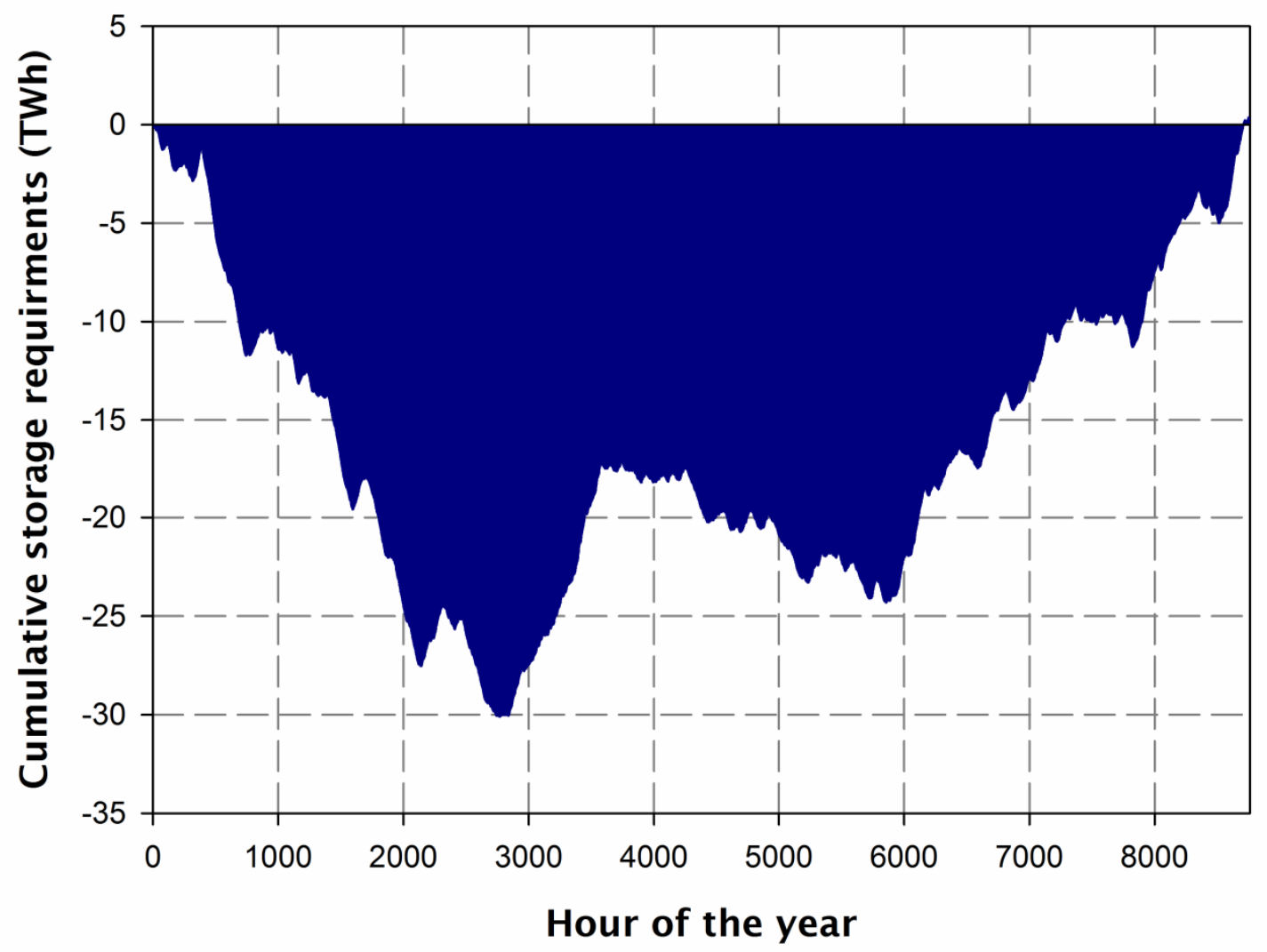

Figure 6: Calculated annual electricity storage profile for the UK BAU scenario

Further analysis was carried out to calculate the required characteristics of an ideal energy storage technology based on the renewable mix calculated for each scenario. These are summarised in Table 8 . In addition to this, three potential large scale energy storage technologies are considered for their suitability in each scenario: pumped storage (PS), liquid air energy storage (LAES) and hydrogen $(\mathrm{H} 2)$. The proposed energy storage technologies have 
electrical, mechanical and state change inefficiencies meaning more installed capacity is required on the grid to account for this. The roundtrip efficiency used for PS facilities is $80 \%$, for LAES technology efficiency is estimated at $60 \%$ (Strbac et al., 2012) and for $\mathrm{H} 2$ the expected value is $45 \%$ for roundtrip efficiency due to the two-step nature of using electricity to produce hydrogen which is stored until it is converted back to electricity through a fuel cell or in direct combustion (Schoenung, 2011). The proposed offshore wind capacity is again scaled in each scenario to accommodate the losses from storing excess generation.

The calculated extra offshore wind capacity required and storage requirements for each scenario are also summarised in Table 8. For example, if the BAU scenario is considered with LAES as the chosen technological solution, the offshore wind capacity required would be $86 \mathrm{CW}+35 \mathrm{CW}=$ $121 \mathrm{GW}$ with $11 \mathrm{GW}$ of installed LAES capacity and $2.3 \mathrm{TWh}$ of storage to ensure demand is met throughout the year.

Table 8: Ideal and calculated energy storage characteristics, plus offshore wind capacity requirements, by scenario (Business as Usual (BAU), Green Plus $(G P), B A U$ with electrification of heating and transportation (BAU+ASHP\&EV) and GP with electrification of heating and transportation (GP+ASHP\&EV)) and by energy storage technology

\begin{tabular}{|l|c|c|c|c|}
\multicolumn{1}{|c|}{ Scenario } & BAU & GP & $\begin{array}{c}\text { BAU + } \\
\text { ASHP\&EV }\end{array}$ & GP + ASHP\&EV \\
\hline $\begin{array}{l}\text { PS rated capacity } \\
\text { (GW) }\end{array}$ & 45 & 60 & 114 & 114 \\
\hline $\begin{array}{l}\text { PS storage capacity } \\
(\text { TWh })\end{array}$ & 9 & 12 & 22 & 23 \\
\hline $\begin{array}{l}\text { PS offshore wind } \\
\text { capacity (GW) }\end{array}$ & +18 & +9 & +26 & +17 \\
\hline $\begin{array}{l}\text { LAES rated capacity } \\
(\text { GW })\end{array}$ & 11 & 35 & 55 & 70 \\
\hline $\begin{array}{l}\text { LAES storage } \\
\text { capacity (TWh) }\end{array}$ & 2.3 & 7 & 11 & 14 \\
\hline LAES offshore wind & +35 & +17 & +51 & +33 \\
\hline
\end{tabular}




\begin{tabular}{|l|c|c|c|c|}
\hline capacity (GW) & & & & \\
\hline $\begin{array}{l}\text { H2 rated capacity } \\
(\mathrm{GW})\end{array}$ & 1 & 26 & 5 & 50 \\
\hline $\begin{array}{l}\text { H2 storage capacity } \\
(\mathrm{TWh})\end{array}$ & 0.15 & 5 & 0.9 & 10 \\
\hline $\begin{array}{l}\text { H2 offshore wind } \\
\text { capacity }(\mathrm{GW})\end{array}$ & +48 & +23 & +70 & +46 \\
\hline
\end{tabular}

Further investigation has been carried out to explore the optimal mix of storage and offshore wind capacity for each scenario in terms of installed capital cost. The capital cost estimate for offshore wind capacity used in this study is $£ 1.78$ million/MW [38]. The cost estimate for PS installations used in this study is $£ 0.92$ million/MW [73]. Estimates of likely costs for the LAES installations are $£ 1.5$ million/MW with a likely reduction to $£ 1.275$ million/MW in the future [74]. It is assumed that the lower cost estimate is achieved in this study. In the case of hydrogen, there are multiple steps involved in generating hydrogen, then storing it in underground caverns of tanks above ground, and finally converting it back to electricity. For this reason cost estimates include the cost of the electrolyser ( $£ 0.207$ million/MW), the fuel cell cost of $£ 0.305$ million/MW and the cost of storage in underground caverns at a cost of $£ 0.0002$ million/MWh or in tanks above ground at $£ 0.0092$ million/MWh [75].

This analysis considered variations in the installed offshore wind capacity and estimates a combined cost for the energy storage required plus wind capacity in order to optimise the size of energy storage and wind capacity to reduce the capital costs. The results of these analyses are illustrated in Figure 7. 


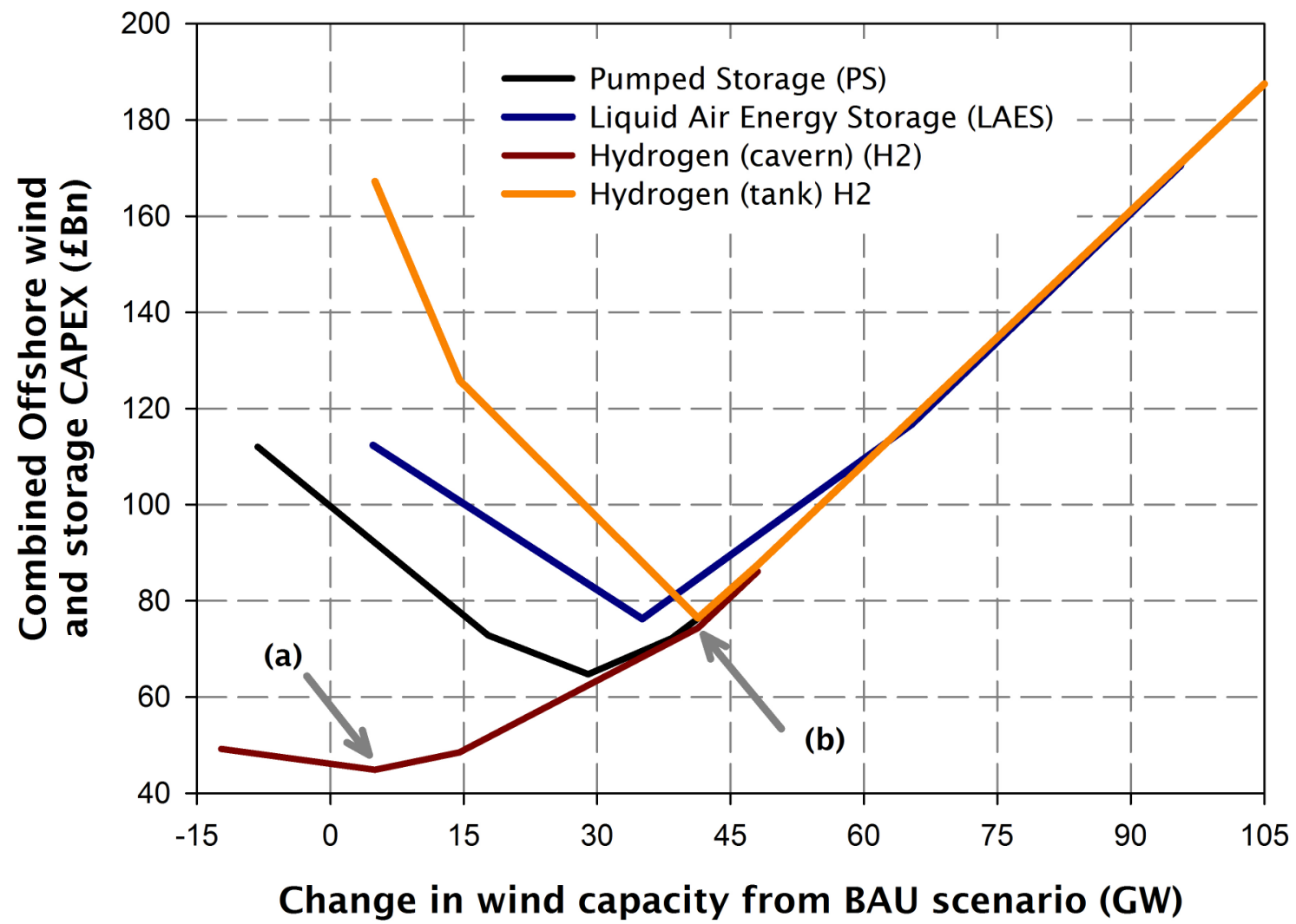

Figure 7: Calculated additional capital expenditure and offshore wind capacity required per energy storage technology to ensure demand is met in the BAU scenario, where (a) is the calculated optimal combination of energy storage (through storing hydrogen in caverns) and the required extra capacity from offshore wind generation required to ensure demand is met throughout the year; and (b) is the calculated cost for a more realistic scenario with 4GW of PS capacity on the network.

In the BAU scenario, the lowest capital cost could be achieved by installing an additional 5GW of offshore wind capacity combined with $65 \mathrm{GW}$ of hydrogen capacity stored in caverns at an additional cost of $£ 45$ billion (see (a) in Figure 7). This has been calculated iteratively by determining the optimal storage capacity required and resolving for the additional wind capacity required to ensure demand is met throughout the year. This 
provides the most cost effective solution between energy storage and extra installed offshore wind capacity.

To put this into context, to date there is a total of $141 \mathrm{GW}$ of installed and operational energy storage capacity worldwide [76], most of which is pumped storage. In the context of the UK, pumped storage facilities are already in operation (for example the $1.6 \mathrm{GW} / 10 \mathrm{GWh}$ capacity Dinorwig facility in North Wales). However, there is only a potential for the total installed rated capacity to be increased to 4GW with a combined storage capacity of $864 \mathrm{GWh}$ [77]. If this is taken to be the maximum capacity available for pumped storage in the UK for BAU scenario, the calculated additional offshore wind capacity is $38 \mathrm{GW}$ and would incur a combined capital cost of $£ 72$ billion (see (b) in Figure 7). To put into context the amount of storage required for LAES, the Isle of Grain liquefied natural gas (LNG) storage facility has been used as a comparison. The facility has a storage capacity of $956,000 \mathrm{~m}^{3}$ [78] and LAES is assumed to need $39,000 \mathrm{~m}^{3}$ to store $1 \mathrm{GWh}$ of energy in liquefied air [79]. In the case of hydrogen storage in caverns, an existing hydrogen storage facility in Teesside that has three $150,000 \mathrm{~m}^{3}$ salt caverns that hold a storage capacity of $24.4 \mathrm{GWh}$ has been used as a reference [80]. The findings of these comparisons are summarised in Table 9. It was found that for a LAES solution, the storage facilities required would be equivalent to 93 of the Isle of Grain facilities. For hydrogen storage in caverns, another 559 storage facilities similar to that at Teesside would be required. 
Table 9: Calculated number of equivalent facilities required for each of the optimum combinations of energy storage and offshore wind for the BAU scenario and the estimated capital cost ( $£ B n)$

\begin{tabular}{|l|c|c|c|}
\hline \multicolumn{1}{|c|}{ BAU scenario } & PS & LAES & H2 (cavern) \\
\hline Storage rated capacity (CW) & 4 & 11 & 65 \\
\hline Storage capacity (GWh) & 864 & 2,272 & 13,645 \\
\hline Offshore wind capacity (GW) & +38 & +35 & +5 \\
\hline $\begin{array}{l}\text { Combined offshore wind } \\
\text { and storage cost }(£ B n)\end{array}$ & 72 & 76 & 45 \\
\hline Equivalent $n^{\circ}$ facilities & - & 93 & 559 \\
\hline
\end{tabular}

From this investigation it can be appreciated that the scale of the storage problem in the fully renewable UK electricity grid is challenging as most suitable sites for PS have already been developed [81]. The planning and construction of enough storage tanks for LAES could be difficult; however, there is a precedent and an existing supply chain. In the case of $\mathrm{H} 2$ storage, the number of suitable sites to accommodate the large number of caverns for hydrogen storage is perhaps debatable. However, the main barriers to these solutions are the economic aspects and the need for more pilot schemes to prove the technological and commercial feasibility of the technologies.

\subsection{Existing UK electricity grid suitability}

As discussed, the UK network is divided into 17 individual zones, within which there is a specific electricity demand and electricity generation [82]. Using these zones, it is possible to determine the future renewable generation by zone for each scenario based on the location of existing and proposed installations. The demand for each zone has been calculated for the future scenarios by linearly scaling the 2011 demand. Using this 
approach, it is possible to investigate the power flows that occur around the UK network and where the demand and generation centres are. It also highlights potential bottlenecks in the network that would require transmission upgrades to cope with the higher power flows. Figure 8 illustrates the power flows around the UK network in 2011 and the calculated power flows for the 2050 BAU scenario.

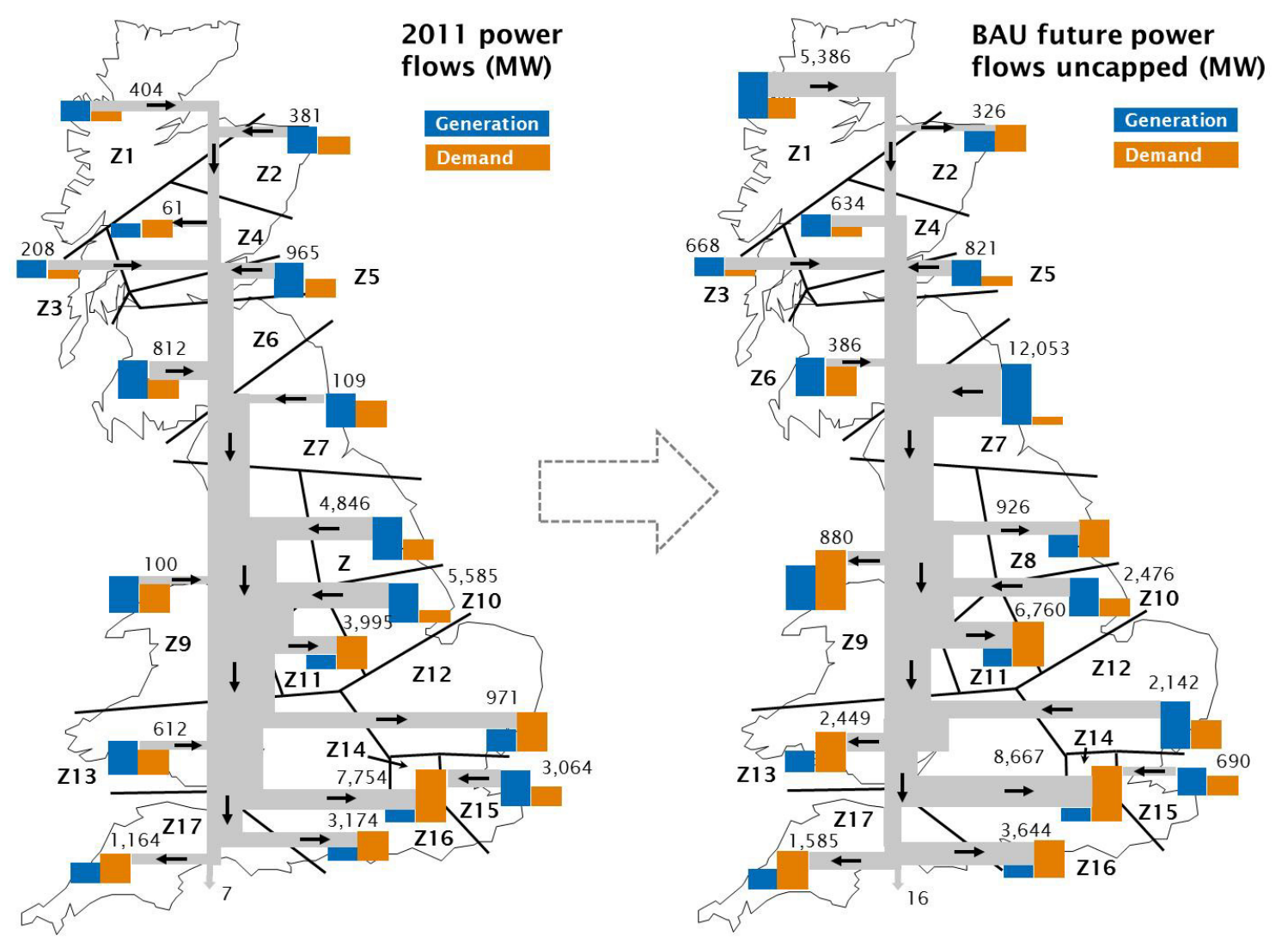

Figure 8: Average electricity power flows across the UK network in 2011 [82] and calculated for 2050 BAU scenario

Due to the large increase in the calculated offshore wind farms in the future scenarios there are larger generation flows in zones 1, 7 and 12 implying that the transmission network would require upgrades here. These 
bottlenecks could also be ideal locations for targeted bulk energy storage installations to ease network congestion and defer transmission upgrades.

\section{Conclusions}

This study has introduced potential renewable energy mixes for the UK that meet proposed annual proposed electricity demands set out in this study. The estimated capital costs for these scenarios range from $£ 200$ to $£ 353$ billion. However, when considering the hourly demand and generation profiles, the issue of generation variability becomes apparent due to the variable sources such as wind and solar PV. It was found that the level of available dispatchable generation in the UK (hydro, bioenergy and geothermal) in these scenarios is insufficient to meet demand when there is only a small contribution from wind due to high pressure systems (anticyclones) across the whole of the UK. A range of technological solutions to balance the generation and demand of UK electricity grid have been discussed. The first option introduced is interconnection between the UK and European electricity networks to import electricity when generation is lower than demand and export surplus electricity when generation is greater than demand. It was calculated that an interconnector capacity of 60GW at an extra cost of $£ 58$ billion would be required for the BAU scenario. However, as discussed, this is dependent on the European electricity network being capable of accommodating these levels of import and export throughout the year. The second option introduced is large scale energy storage considering pumped storage (PS), liquid air energy storage (LAES) or hydrogen (H2) as potential solutions. Analysis was carried by varying the amount of offshore 
wind capacity and energy storage capacity to find optimum solutions. It was found that for the BAU scenario the optimum solution would be $65 \mathrm{GW}$ of rated hydrogen capacity and $13,645 \mathrm{GWh}$ of storage in underground caverns with an extra 5GW of wind capacity at an additional cost of $£ 45$ billion. However, there remain some uncertainties as to the technological and commercial viability of this option as there are no real world applications of this solution to date. A more realistic solution would be to utilise 4GW of rated pumped storage capacity (864GWh storage capacity) with an extra wind capacity of $38 \mathrm{GW}$ at an estimated additional cost of $£ 72$ billion. This solution employs mature technology which has been proven to work on electricity grids at large scales.

In reality, a mix of interconnection and energy storage technologies is required to ensure the future highly variable electricity grid is viable. Further detailed investigations are required to fully understand the likely combinations as this is a complex question. The trade-offs to be investigated centre around the location of interconnectors and energy storage: hydrogen storage in salt caverns is constrained to the North-West of England and would require network upgrading to transmit the electricity, whereas interconnectors can be installed where required closer to the load centres. In addition, consumer behaviour towards electricity usage will help reduce the amount of balancing required. However, one of the most important factors to the viability of the fully renewable electricity grid is the market structure and the governing energy policy. Furthermore, investment in key 
network upgrades and renewable capacity is needed now in order to safeguard the future electricity grid.

\section{Acknowledgements}

This study is supported by the Engineering and Physical Sciences Research

Council (EPSRC) through the Industry Doctoral Training Centre (IDTC)

Transport and the Environment at the University of Southampton.

\section{References}

1. EC. Roadmap 2050 - Sectoral perspective. 201108 March 2011 [cited 2012 September]; Available from:

http://ec.europa.eu/clima/policies/roadmap/perspective/index_en.ht m.

2. DECC, Smarter Grids: The Opportunity, D.o.E.a.C. Change, Editor. 2009, Crown Copyright: London.

3. Milborrow, D. and S. Gonzalez, The Carbon Trust \& DTI Renewables Network Impact Study Annex 4: Intermittency Literature Survey \& Roadmap. 2003, Mott MacDonald: Brighton, UK.

4. Glasnovic, Z. and J. Margeta, Vision of total renewable electricity scenario. Renewable and Sustainable Energy Reviews, 2011. 15: p. 1873-1884.

5. Heide, D., et al., Seasonal optimal mix of wind and solar power in a future, highly renewable Europe. Renewable Energy, 2010. 35: p. 2483-2489.

6. Trainer, T., Can Europe run on renewable energy? A negative case. Energy Policy, 2013.

7. Steinke, F., P. Wolfrum, and C. Hoffmann, Grid vs. storage in a $100 \%$ renewable Europe. Renewable Energy, 2013. 50: p. 826-832.

8. Lund, H. and B.V. Mathiesen, Energy system analysis of $100 \%$ renewable energy systems-The case of Denmark in years 2030 and 2050. Energy, 2009. 34: p. 524-531.

9. Cosic, B., G. Krajacic, and N. Duic, A $100 \%$ renewable energy system in the year 2050: The case of Macedonia. Energy, 2012. 48: p. 80-87.

10. Krajacic, G., et al., Planning for a 100\% independent energy system based on smart energy storage for integration of renewables and $\mathrm{CO}$ emissions reduction. Applied Thermal Engineering, 2011. 31: p. 20732083.

11. Krajacic, G., N. Duic, and M. Da Graca Carvalho, How to achieve a 100\% RES electricity supply for Portugal. Applied Energy, 2011 . 88: p. 508517. 
12. Connolly, D., et al., The first step towards a $100 \%$ renewable energysystem for Ireland. Applied Energy, 201 1. 88: p. 502-507.

13. Mason, I.G., S.C. Page, and A.G. Williamson, A 100\% renewable electricity generation system for New Zealand utilising hydro, wind, geothermal and biomass resources. Energy Policy, 2010. 38: p. 39733984.

14. Elliston, B., M. Diesendorf, and I. MacGill, Simulations of scenarios with $100 \%$ renewable electricity in the Australian National Electricity Market. Energy Policy, 2012. 45: p. 606-613.

15. Ostergaard, P.A., et al., A renewable energy scenario for Aalborg Municipality based on low-temperature geothermal heat, wind power and biomass. Energy, 2010. 35: p. 4892-4901.

16. Ostergaard, P.A. and H. Lund, A renewable energy system in Frederikshavn using low-temperature geothermal energy for district heating. Applied Energy, 2011. 88: p. 479-487.

17. Krajacic, G., N. Duic, and M. Da Graca Carvalho, $\mathrm{H}_{2}$ RES, Energy planning tool for island energy systems-The case of the Island of Mljet. Hydrogen Energy, 2009. 34: p. 7015-7026.

18. Segurado, R., et al., Increasing the penetration of renewable energy resoources in S. Vicente, Cape Verde. Applied Energy, 2011 . 88: p. 466-472.

19. Duic, N. and M. da Graca Carvalho, Increasing renewable energy sources in island energy supply: case study Porto Santo. Renewable and Sustainable Energy Reviews, 2004. 8: p. 383-399.

20. Zervos, A., C. Lins, and J. Muth, RE-thinking 2050-A 100\% Renewable Energy Vision for the European Union. 2010, European Renewable Energy Council: Brussels, Belgium.

21. Lund, H., Large-scale integration of wind power into different energy systems. Energy, 2005. 30: p. 2402-2412.

22. Lund, H., Renewable energy strategies for sustainable development. Energy, 2007. 32: p. 912-919.

23. Lund, H., et al., From electricity smart grids to smart energy systems A market operations based approach and understanding. Energy, 2012. 42: p. 96-102.

24. NationalGrid. 2012 Electricity Ten Year Statement (TYS). 2013 [cited 2013 February]; Available from:

http://www.nationalgrid.com/uk/Electricity/ten-yearstatement/current-elec-tys/.

25. MetOffice. Average December finishes a warm 2011.2011 [cited June 2012]; Available from:

http://www.metoffice.gov.uk/news/releases/archive/2011/decemberand-annual-statistics.

26. DECC, Weather Statistics - Average wind speed and deviations from the long term mean (ET 7.2). 2012, Department of Energy and Climate Change.

27. NationalGrid. Metered half-hourly electricity demands. 2013 [cited 2013 January]; Available from:

http://www.nationalgrid.com/uk/Electricity/Data/Demand+Data/. 
28. ELEXON. Generation by Fuel Type - Raw Data. 2013 [cited 2013 25.04.2013]; Available from:

https://www.elexonportal.co.uk/article/view/216?cachebust=fxwjq4nl

oz.

29. MetOffice. Met Office Integrated Data Archive System (MIDAS) Land and Marine Surface Stations Data (1853-current). 2012 [cited 2013 03.06.2013].

30. NERC, Hourly modelled tidal data for 2001 at location $58.7160 \mathrm{~N}$, 3.1150 W, N.E.R.C. (NERC), Editor. 2013: Liverpool, UK.

31. Elders, I., et al., Electricity Network Scenarios for Great Britain in 2050. 2006, Institute for Energy and Environment: Glasgow.

32. Boardman, B., et al., 40\% House. 2005, Environmental Change Institute: Oxford.

33. Hassett, B., E. Bower, and M. Alexander, MERGE WP 3 Task 3.2: Evaluation of the impact that progressive deployment of EV will provoke on electricity demand, steady state operation, market issues, generation schedules and on the volume of carbon emissions. 2011, Ricardo: European Commission.

34. DECC. Digest of UK Energy Statistics (DUKES) - Chapter 5: Electricity. 2012 [cited 2013 January]; Available from:

http://webarchive.nationalarchives.gov.uk/20130109092117/http://d ecc.gov.uk/en/content/cms/statistics/energy_stats/source/electricity/ electricity.aspx.

35. Blecourt, M.d., Load-shifting in a new perspective - smart scheduling of smart household appliances using an agent-based modelling approach, in Faculty of Technology, Policy and Management. 2012, Delf University of Technology: Delf. p. 106.

36. FrontierEconomics and SustainabilityFirst, Demand side response in the domestic sector - a literature review of major trials, D.o.E.a.C. Change, Editor. 2012, Crown copyright: London. p. 156.

37. Gardner, P., UK generation and demand scenarios for 2030. 2011, Garrad Hassan \& Partners Ltd: Glasgow.

38. Arup, Review of generation costs and deployment potential of renewable electricity technologies in the UK. 2011, Ove Arup \& Partners Ltd: London.

39. Ernst\&Young, Cost of and financial support for wave, tidal stream and tidal range generation in the UK. 2010, Ernst \& Young LLP and Black \& Veatch.

40. Estate, T.C., UK Offshore Wind Report. 2012, The Crown Estate: London.

41. 4COffshore. Offshore Wind Farms Database. 2013 [cited 2013 June 2013]; Available from: http://www.4coffshore.com/windfarms/.

42. DCLG, Planning practice guidance for renewable and low carbon energy, D.f.C.a.L. Government, Editor. 2013, Crown copyright: London.

43. DECC, Consultation on changes to financial support for solar PV, D.o.E.a.C. Change, Editor. 2014, Crown Copyright: London.

44. GRO. Estimates of Households and Dwellings in Scotland. 2013 [cited 2013 08.04.2013]; Available from: http://www.groscotland.gov.uk/statistics/theme/households/estimates/index.html. 
45. ONS. 2011 Census, Population and Household Estimates for England and Wales. 2012 [cited 2013 08.04.2013]; Available from:

http://www.ons.gov.uk/ons/publications/re-reference-

tables.html?edition=tcm\%3A77-257414.

46. DECC, Weekly solar PV installation \& capacity based on registration date. 2014, Crown Copyright.

47. TRNSYS. TRNSYS Transient System Simulation Tool. 2013 [cited 2013 July 2013 ]; Available from: http://www.trnsys.com/.

48. NOC. Tidal energy from UK coastal waters. 2013 [cited 2013 July 2013]; Available from: http://noc.ac.uk/news/tidal-energy-from-ukcoastal-waters.

49. Hardisty, J., The Tidal Stream Power Curve: A Case Study. Energy and Power Engineering, 2011 . 4: p. 132-136.

50. Drax. About Drax's biomass plans. 2013 [cited 2013 November 2013]; Available from: http://www.drax.com/biomass/cofiring_plans/.

51. SKM, Geothermal Energy Potential in Great Britain and Northern Ireland. 2012, Sinclair Knight Merz: London.

52. DECC and WAG, England and Wales Hydropower Resource Assessment. 2010, Department of Energy and Climate Change

Welsh Assembly Government.

53. Forrest, N., et al., Scottish Hydropower Resource Study. 2008, Nick Forrest Associates

SISTech

Black \& Veatch.

54. Gross, R., et al., Renewables and the grid: understanding intermittency. Proceedings of the Institution of Civil Engineers - Energy, 2007. 160: p. 31-41.

55. Saguan, M., et al., The UK Charging System on Interconnectors. 2011 , Florence School of Regulation: Florence, Italy.

56. NationalGrid. Interconnectors. 2012 [cited 2012 June]; Available from: http://www.nationalgrid.com/uk/interconnectors/.

57. Purvins, A., et al., A European supergrid for renewable energy: local impacts and far-reaching challenges. Journal of Cleaner Production, 2011. 19: p. 1909-1916.

58. Battaglini, A., et al., Development of SuperSmart Grids for a more efficient utilisation of electricity from renewable sources. Journal of Cleaner Production, 2009. 17: p. 911-918.

59. Hulle, F.V., Integrating Wind - Developing Europe's power market for the large-scale integration of wind power, in TradeWind. 2009, European Wind Energy Association.

60. Czisch, G. and G. Giebel, Realisable scenarios for a future electricity supply based 100\% on renewable energies, in Riso International Energy Conference. 2007: Riso, Denmark.

61. SKM, Offshore grid development for a secure renewable future - a UK perspective. 2010, Sinclair Knight Merz: Newcastle upon Tyne, UK.

62. Ruberg, S., et al., D1.2.1 Improving network controllability by Flexible Alternating Current Transmission Sytem (FACTS) and by High Voltage 
Direct Current (HVDC) transmission systems. 2010, Technical

University Dortmund.

63. Chote, R., S. Nickell, and G. Parker, Economic and fiscal outlook, O.f.B. Responsibility, Editor. 2012, Crown copyright.

64. DECC, Quaterly Energy Prices - December 2012, D.o.E.a.C. Change, Editor. 2012, Crown Copyright: London.

65. Black, M. and G. Strbac, Value of storage in providing balancing services for electricity generation systems with high wind penetration. Journal of Power Sources, 2006. 162: p. 949-953.

66. Grant-Wilson, I.A., P.G. McGregor, and P.J. Hall, Energy storage in the UK electrical network: Estimation of the scale and review of technology options. Energy Policy, 2010. 38: p. 4099-4106.

67. Grant-Wilson, I.A., et al., Grid-connected renewables, storage and the UK electricity market. Renewable Energy, 2011. 36: p. 2166-2170.

68. Connolly, D., et al., The technical and economic implications of integrating fluctuating renewable energy using energy storage. Renewable Energy, 2012. 43: p. 47-60.

69. Evans, A., V. Strezov, and T.J. Evans, Assessment of utility energy storage options for increased renewable energy penetration.

Renewable and Sustainable Energy Reviews, 2012. 16: p. 4141-4147.

70. Koohi-Kamali, S., et al., Emergence of energy storage technologies as the solution for reliable operation of smart power systems: A review. Renewable and Sustainable Energy Reviews, 2013. 25: p. 135-165.

71. Kouskou, T., et al., Energy storage: Applications and challenges. Solar Energy Materials \& Solar Cells, 2014. 120: p. 59-80.

72. Denholm, P. and R. Sioshansi, The value of compressed air energy storage with wind in trasnmission-constrained electric power systems. Energy Policy, 2009(37): p. 3149-3158.

73. Strbac, G., et al., Strategic Assessment of the Role and Value of Energy Storage Systems in the UK Low Carbon Energy Future. 2012, Energy Futures Lab, Imperial College London: London, UK.

74. Arbon, I., et al. Round Table 1 - Liquid Air and the Electricity Grid. 2013.

75. Schoenung, S., Economic Analysis of Large-Scale Hydrogen Storage for Renewable Utility Applications. 2011 , Sandia National Laboratories: Albuquerque, New Mexico, USA.

76. DOE, DOE Global Energy Storage Database. 2012, Sandia Corporation.

77. MacKay, D.J., Sustainable Energy - Without the Hot Air. 2009, Cambridge, UK: UIT Cambridge Ltd. 368.

78. NationalGrid, National Grid LNG - UK leaders in LNG importation. 2009, National Grid: Kent.

79. Trompeteler, P., Discussion about LAES and Isle of Grain storage facility, M. Alexander, Editor. 2013: Shoreham-By-Sea, UK.

80. Ozarslan, A., Large-scale hydrogen energy storage in salt caverns. Hydrogen Energy, 2012. 37: p. 14265-14277.

81. Barton, J., et al., The evolution of electricity demand and the role for demand side participation, in buildings and tranport. Energy Policy, 2013. 52: p. 85-102. 
82. NationalGrid. 2011 National Electrical Transmission System (NETS) Seven Year Statement. 2011 [cited June 2012]; Available from: http://www.nationalgrid.com/uk/Electricity/SYS/current/. 